\title{
Impact of Albanian Folklore in Literature
}

MA. Ermelinda Kashahu

\author{
University "Eqrem Cabej" \\ Faculty of Education and Social Sciences \\ Department of Literature \\ Gjirokastër, Albania \\ ekashahu@gmail.com \\ Edlira Dhima \\ Ismail Qemal University of Vlora \\ College of Human Sciences \\ Department of Language and Literature \\ Vlora, Albania \\ E-mail:edadhima@gmail.com
}

Doi:10.5901/ajis/2013.v2n1p253

\section{Abstract}

Folklore has a really important place in the literature of this country, where we can mention the (Cikli $i$ Kreshnikeve) (The Cycle of the Valiant Heroes), and their opponents, "Kral-s" and "kapedan-s". Along with the epos, Albanians had created also the fund of the ballades, which came like shocking memories of the past ages. One of them is that which is known in the south with the name of Konstandin and Doruntine', whereas in the north "Kënga e Halil Garrisë" (The song of Halil Garria). There are other authors who have being strongly inspited by the Albanian oral poetry, which is included in the "Cikli $i$ Kreshnikeve" (The Cycle of the Valiant Heroes), while in the "Lahuta e Malëcise" (The Lute of Malecia). Another poet is Palaj Bernardin. Palaj is classic lyrics and elegiac author, who published the majority of his works in thirty years in the Franciscan magazine "Hylli i Drites" (Star of the light). The folklore is and will remain an invaluable asset for the Albanians, and will continue to be an inspiration for artists in the future, as it was in the past.

Key words: Folklore, collectors, Albanian literature

\section{Introduction}

The folklore has indeed an important role in the literature of this country. Our folklore is very rich, where we can mention the 'Ciklin e Kreshnikeve' (The Cycle of the Valiant Heroes), with Muji ${ }^{1}$ and Halil ${ }^{2}$, Gjergj Elez Alia ${ }^{3}$ etc. in the centre of this cycle stand the jobs of the file of the Valiant Heroes, as

\footnotetext{
I "The history of the Albanian literature" a publication of University of Tirana I959, volume I page 3-I36.

${ }^{2}$ Marchiano, Canti polulari, albanezi delle colonie d'Italia, Foggia I908, p. 26.

${ }^{3}$ R. Sokoli, On the songs of work in our folklore, "Nentori” magazine, February I995, p. I29.
} 
well as their opponents, the "kral-s"4 and "kapedan-s"5 [I] especially from the coastal regions. The war of the Valiant Heroes is situated at a time and in an environment that does not acknowledge yet the fire guns. Their content and the social outlook, the artistic elements they contain, the Songs of the Valiant Heroes send you back to an earlier period than that of the Ottoman occupation. Along with the epos, Albanians had created also the fund of the ballades, which came like shocking memories of the past ages. One of them is that which is known in the south with the name of 'Konstandin and Doruntine', whereas in the north "Kënga e Halil Garrisë" (The song of Halil Garria). [2] The ballade of 'Kostandin and Doruntine is often treated as a masterpiece which raises the cult of 'besa' (trust), the sanctity of the given word, for the sake of which the curse could follow you in this life and the other. The message of 'besa' (trust) is present in the breath of the ballade, but before this message is the breath of the human power to come back to this life. In addition to the oral creativity, at this time began to emerge many other writings such as the 'koleksioni i kodikëve' (collection of the codices) which constitutes one of the most important cultural resources of the Albanian people. This collection contains over 100 volumes, which constitute complete works (manuscripts) and 17 fragments. The Codices of Albania, the oldest of which is "Kodiku i Purpurt i Beratit" (Purple Codex of Berati), are an important fund for the history of the development of the old biblical literature. [3]All these important parts of the Albanian folklore, earlier Albanian write a great drive for the continuance of the Albanian literature. These works became an inspiration for the young authors, who owing to them they became acquainted with the good and bad in the art. These works were not just an inspiration for the Albanian literature, but they also became a drive for the cinematography, ballet and many other fields of the Albanian art. It should be said that, many intellectuals of the renaissance were educated and were influenced by the European breath of that time but yet they did not forgot the folklore. From these legends are created works of a worldwide fame, such as the work of Ismail Kadare "Kush e solli Doruntinen"(Who brought Doruntina home), based on the tradition. Another case is that of Mitrush Kuteli, who took enough of the elements of his narrations from the 'Tosk' ${ }^{6}$ folklore, the way he had heard it in his childhood and exploited it to recreate clear motives of life in the countryside. Among these works where Kuteli made the folklore a part of his creativity, we can mention here: 'Ago Jakupi' and other narrations, a summary of seven narrations about life in the countryside; 'Kapllan Aga i Shaban Shpatës' (Kapllan Aga son of Shaban Shpata). [4] Narrations - Tales, etc. Another poet, in whose works catch the eye, the close ties with oral literature, is Fishta, even though some authors have criticized Fishta for 'folklorism', for the imitation of the folklore, without being able to create a real epic poem. It is worthy to be mentioned that Fishta is mightily inspired by the Albanian oral poetry, as well as by the cycles of heroic poetry called 'Këngë kreshnikësh' (Songs of Valiant Heroes) when he wrote 'Lahuta e malcis'. [5] Another poet dedicated to the folklore was Bernardin Palaj. Palaj is also an author of classical and elegiac lyrics, in the most part published in the years '30 in the Franciscan magazine 'Hylli i Dritës' (Star of the light). [6]The folklore is and will remain an invaluable resource for the Albanians, and will continue to be an inspiration for artists in the future, the way it was in the past...

Every people create its art and culture. Our people have also done this since in the earlier times, since the writing was not yet invented. Thus our people has created songs and fairy tales, legends and proverbs, the cycle of the valiant heroes and riddles, their characteristic music and dances, their rich costumes and their various habits, their special way of building houses, bridges, castles etc., In this way, in addition to other things, they have expressed the richness of their fantasy, the ability to create genuine

\footnotetext{
${ }^{4}$ Lyric folk songs, Tirana I955, p. 294.

${ }^{5}$ The Archive of the Albanian Folklore (Z. Sako)

${ }^{6}$ The Nation's Depositories, Volume III, Tirana, I937, p. I3I.
} 
art works, be it words, be it the diversity of the costumes, be it musical melody etc. This way, they had continuously brought their part in the culture and art of humanity, in the world civilization.

This entire cultural and artistic heritage, earlier it has been a habit to be called folklore, a word derived from English (folk-people and lore-knowledge of art). Later with this name was called only that what was created by the people. Albanian folklore is very rich. Our thinker, Branko Merxhani, who highly evaluated our folklore, speaks more than once about the necessity of learning of this resource by us. [7]

"We should enter within the people, - he writes, - and live along with the people, to cognize their sayings and natrations of their traditions; to follow the way of thinking and the thythm of their feelings; to enter inside in the "understanding of their religious life and to understand the feelings of their morals. Such a great endless and headless "school", a whole lively university is the life of the people (...). From this school of popular life emerged the genies of history"?

Has the folklore had influence in the Albanian "literature"?

Certainly yes..., During its history, the literature has been a bearer and the first source of the acknowledgement of the mythology, an expressive of the biblical thought, religious in general, laudatory of the creative power of the human being, an analytical mirror of the individual and the society, an elaborator and a spreader of the revolutionary thought etc., by remaining at the same time artistically organized word, with the natural tendency to make a life distinguished from other activities.

This is our folklore, with a clear beauty, understood and experienced. The folklore is conserved orally by passing from a generation to the other. Therefore, it is exactly the popular memory that which conserves it, and has made it able that the songs, fairy tales, proverbs etc., to not be lost and that every good part of the ancient folklore to come to our days.

In the beginning of the nineteenth century scholars from different countries began to show a great interest about the folklore, because in it, in addition to an artistic treasure, they saw also characteristics which determine features

In the year 1635 we find an Latin-Albanian dictionary of the author Frank Bardhi which included some proverbs; later on the Arbëresh ${ }^{8}$ of Italy, the great poet Jeronim De Rada publishes in I866 a book with different songs entitled "Rhapsody of an Albanian Poem gathered in the region of Napoli"; Zef Jubani publishes in I87I a "Summary of folk songs and rhapsodies of Albanian poems" whereas in the year I878 Thimi Mitko publishes the most known folkloric summary "Albanian Bee". It is worthy to mention here the summary entitled "Sea Waves" (I898) of the author Spiro Dine. [8]

The most distinguished Albanian folklorists are: Zef Jubani, Jeronim De Rada, Bernardin Palaj, Ernest Koliqi, Qemal Haxhihasani, Ramadan Sokoli etc. One of the characteristics is the collective feature. We emphasize here that the collectors of the 'Cycle of The Brave Heroes' at the 'Nation's Depositories' have also written down the names of the rhapsodists, who have sang masterpieces such as: "Kenga e Gjergj Elez Alisë" (The Song of Gjergj Elez Alia), "Martesa e Halilit" (The Marriage of Halil) etc. According to Naim, the folklore as a permanent demand had its influence in the Albanian literature. [9] It could support the point of views on the ancientness of the Albanians, without dealing with mythology and their antique polytheism, without holding on after the ancientness and originality.

${ }^{7}$ M. Xhaxhiu, Literature and Folklore, The poem "Narrations of the Arbër" and problems of the poetry of De Rada.

${ }^{8}$ A. Xhangolli, Folkloric Literature, Prishtina I996, Bogdani, R.

${ }^{9} \mathrm{Gj}$. Zheji, Cajup and the folklore, on "Nentori", Tirane, I966. 
In supporting this opinion let us mention as an example the song "Kur mërzen cjapi me zile" (When the Billy goat with a bell rests in the shade), which has become one of the most preferred lyric folk songs of the southeastern regions of the country (Përmet, Skrapar, Korçë, Pogradec etc). The various variants of this song are registered as a text or as a melody and they conserve the essential idea.

The influence of the folklore appears often also in the poem "History of Scanderbeg" about which in any case is said that it does not contain obvious layers of the folkloric resource. But it is certain that the poet heard something, perhaps by his close friend Halit Bërzeshta.

At the Albanians of Italy, as it appears in a folkloric summary of Jeronim De Rada and Kamarda, the tradition of ....... has been alive. From the Albanian emigration, in those few elements we have from their folk culture, we find a lyrical wedding song. This song is heard even nowadays in Gjirokastra.

\section{Bibliography}

"The history of the Albanian literature" a publication of University of Tirana 1959, volume I page 3-I36. Marchiano, Canti polulari, albanezi delle colonie d'Italia, Foggia I908, p. 26.

R. Sokoli, On the songs of work in our folklore, "Nentori" magazine, February 1995, p. 129.

Lyric folk songs, Tirana I955, p. 294.

The Archive of the Albanian Folklore (Z. Sako)

The Nation's Depositories, Volume III, Tirana, 1937, p. I3I.

M. Xhaxhiu, Literature and Folklore, The poem "Narrations of the Arbër" and problems of the poetry of De Rada.

A. Xhangolli, Folkloric Literature, Prishtina 1996, Bogdani, R.

Gj. Zheji, Çajup and the folklore, on "Nentori”, Tirane, I966. 